\title{
Physicochemical Quality of Kernels from Terminalia catappa L. and Sensory Evaluation of the Concocted Kernels
}

\author{
Godi H. M. Biego ${ }^{1,2}$, Amoin G. Konan ${ }^{1,3}$, Togba E. Douati ${ }^{1} \&$ L. P. Kouadio ${ }^{2}$ \\ ${ }^{1}$ Laboratory of Biochemistry and Food Science, Faculty of Biosciences, University of Abidjan-Cocody, Abidjan, \\ Côte d'Ivoire \\ ${ }^{2}$ Department of Public Health, Hydrology and Toxicology, Faculty of Pharmaceutical and Biological Sciences, \\ University of Abidjan-Cocody, Abidjan, Côte d'Ivoire \\ ${ }^{3}$ Centre Suisse de Recherches Scientifiques en Côte d'Ivoire, Adiopodoumé, Côte d'Ivoire \\ Correspondence: Godi H. M. Biego, Laboratory of Biochemistry and Food Science, Faculty of Biosciences, \\ University of Abidjan-Cocody, Côte d'Ivoire. Tel: 225-0701-8836. E-mail: biegoh3@yahoo.fr
}

Received: March 27, 2012 Accepted: April 28, 2012 Online Published: June 27, 2012

doi:10.5539/sar.v1n2p1 URL: http://dx.doi.org/10.5539/sar.v1n2p1

\begin{abstract}
This study focused on the physicochemical characterization of the kernels from Terminalia catappa L. and sensory evaluation of appetizers concocted from these kernels. The results of the physicochemical analyzes were as follow: ash $(4.0 \pm 0.1 \%)$, proteins $(40.9 \pm 1.3 \%)$, lipids $(50.6 \pm 1.0 \%)$, total sugars $(1.4 \pm 0.1 \%)$, reducing sugars $(0.3 \pm 0.01 \%)$ and moisture content $(3.8 \pm 0.4 \%)$. Acid and peroxide values were respectively $1.3 \pm 0.2 \%$ and $6.30 \pm 0.23$ meq $\mathrm{O}_{2} / \mathrm{kg}$ oil. Two appetizers were concocted from the fresh kernels of Terminalia catappa L: Salted Roasted Kernels (SRK) and Unsalted Roasted Kernels (URK). A comparison of sensory profiles of both appetizers showed that they were not significantly different $(p<5 \%)$ for the parameters sweet and oily but different $(\mathrm{p}<5 \%)$ for the parameters salty, bitter and firm. However, the tasters' preference for the Salted Roasted Kernels was not significantly different from their preference for the Unsalted Roasted Kernels. The appetizers from Terminalia catappa L. (SRK and URK) were then compared to other appetizers readily available in markets and malls: Salted Roasted Peanuts (SRP), Unsalted Roasted Peanuts (URP), Unsalted Roasted Hazelnuts (URH) and Salted Roasted Cashew nuts (SRC). The preference order was: $\mathrm{URH}<\mathrm{URK}<\mathrm{SRK}<\mathrm{URP}<\mathrm{SRC}<\mathrm{SRP}$.
\end{abstract}

Keywords: kernels, appetizers, Terminalia catappa L., sensory evaluation, physicochemical analyzes

\section{Introduction}

Terminalia catappa L. is a tropical tree of the Combretaceae family encountered in many tropical regions. Native to tropical Asia, this tree was introduced in Côte d'Ivoire during colonization for urban ornamentation (Cavalcante, Maia, Figuieredo, \& Teeixeira, 1986). From the 2000s, some farmers have become interested in the popularization of this tree for the sale of its dried fruits. From the scientific point of view, various studies, mainly on the chemical composition and nutritional value of Terminalia catappa kernel and pulp, have been carried out (Dos Santos et al., 2008). The results of various investigations have shown that the pulp contains mostly carbohydrates (11.05 to $14.05 \%$ ), vitamin C (95.9 to $138.6 \mathrm{mg} / 100 \mathrm{~g}$ of pulp) and $\beta$-carotene (754-2090 $\mu \mathrm{g} / 100 \mathrm{~g}$ of pulp in the red variety) (Dikshit \& Samudrasok, 2011). They also revealed the presence of saponins, glycosides, flavonoids, alkaloids, anthraquinones, anthraquinone glycosides, terpenoids and steroids (Oduro, Larbie, Amoako, \& Antwi-Boasiako, 2009; Matos et al., 2009). The kernels of Terminalia catappa are good sources of proteins rich in essential amino acids (22-25\%), lipids (35-52\%), unsaturated fatty (oleic acid and linoleic acid), and minerals among which the most important are potassium $(9280 \pm 0.14 \mathrm{mg} / 100 \mathrm{~g})$, calcium $(827.20 \pm 2.18 \mathrm{mg} / 100 \mathrm{~g})$ and magnesium $(798.6 \pm 0.32 \mathrm{mg} / 100 \mathrm{~g})$ (Oduro et al., 2009; Matos et al., 2009; Ezeokonkwo \& Dodson, 2004; Nwosu, Dosumu, \& Okocha, 2008). Studies on the nutritional value and biological activity of the kernel of Terminalia catappa revealed that it has a good digestibility, exerts a strong antioxidant activity, possesses anti-HIV properties, anti-asthma properties, anti-inflammatory, anti-carcinogenic, antibacterial and hepatoprotective properties (AOAC, 1975; Dorsch \& Wagner, 1991; Ko, Weng, \& Chiou, 2002; Ko, Weng, Lin, \& Chiou, 2003; Lin, Hsu, \& Lin, 1999; Nagappa, Thakurdesai, Venkat, \& Singh, 2003; Teotia \& Singh, 1997; Atnasooriya \& Dharmasiri, 2000). In view of all this potential, it is critically important to promote processing and consumption of this tropical fruit. In fact, despite its many nutritional benefits and its beneficial 
effects on health, processing of Terminalia catappa is not widespread and its consumption is limited to a few fruits picked up by children under this tropical tree, mostly used for ornamentation purposes. Moreover, despite the expansion in West Africa of appetizers based on local foods such as yams, peanuts, cashews, plantains and maize (Attaie, Zakhia, \& Bricas, 1997), those derived from the fruit or kernels of Terminalia catappa remain unexplored. This study was therefore undertaken to firstly determine the physicochemical properties of the kernels of Terminalia catappa and secondly evaluate the sensory properties of appetizers concocted from these kernels.

\section{Material and Methods}

\subsection{Preparation of Terminalia Catappa Kernels}

The biological material was made up of kernels of Terminalia catappa L. obtained from ripe fruits collected in Abidjan (on the campus of the University of Abidjan-Cocody and in the neighborhoods of Treichville and Plateau). From September 2009 to March 2010, $150 \mathrm{~kg}$ of fruit (MF) were collected (50 kg per site). After collection, the fruits were dried in the sun for a week until the kernels are extractable. The kernels were then extracted from shells with a nutcracker and weighed again (MA). The whole kernels were used for sensory tests, while those that were broken went towards the physicochemical characterization. The yield of the obtained kernels (PA) was determined using the following formula:

$$
\mathrm{PA}=\mathrm{MA} \times 100 / \mathrm{MF}
$$

Where MA is the extracted kernels and MF is the whole collected fruits.

\subsection{Physicochemical Analyzes}

The physicochemical characterization focused on the determination of ash content (Bureau Interprofessionnel d'Etudes Analytiques [BIPEA], 1976), moisture content (Association of Official Analytical Chemists [AOAC], 1975), proteins (BIPEA, 1976), lipids (AOAC, 1975), total sugars (Dubois, Gilles, Hamilton, Rebers, \& Smith, 1956) and reducing sugars (Bernfeld, 1955). The acid and peroxide values were determined from the oil extracted from dried kernels according to AOAC methods (AOAC, 1975) and by Cocks and Rede (1996). Each analysis was performed in triplicate.

\subsection{Concoction and Sensory Evaluation of Appetizers}

\subsubsection{Concoction of Appetizers}

The whole kernels of Terminalia catappa were salted or not and then roasted. Roasted Salted (or not) peanuts, roasted unsalted hazelnuts and roasted salted cashew nuts were bought at a supermarket in Abidjan and used for sensory evaluation.

\subsubsection{Sensory Evaluation}

Sensory evaluation of the concocted appetizers was based upon methods described by Meilgaard, Civille, \& Carr (1999). Two types of tests were conducted: the descriptive quantative and the preference tests.

\subsubsection{Descriptive Quantitative Test}

The establishment of the sensory profiles of appetizers concocted from the kernels of Terminalia catappa (URK and SRK) was conducted by a panel of 10 volunteers selected and trained for one and a half month. During kernels samples evaluation, each volunteer had to taste the Terminalia-based appetizers. After tasting, the panelist had to assign for each descriptor (sweet, salty, bitter, firm and oily), a mark of the perceveid intensity on a linear scale of $10 \mathrm{~cm}(100 \mathrm{~mm})$ which left end indicates the lowest intensity of the descriptor (not sweet for instance) and the right end, the greatest intensity (extremely sweet for instance). Three sessions were held for this evaluation. The average intensity for each descriptor was then calculated and the sensory profiles were established.

\subsubsection{The Preference Tests}

Two preference tests were performed: the paired preference test and the preference ranking test as described by Meilgaard et al. (1999). The former was designed to compare Terminalia-based appetizers (SRK and URK) and the latter was performed to compare Terminalia-based appetizers (SRK and URK) to other appetizers sold in commerce and commonly consumed by Ivorians: Salted Roasted Peanuts (SRP), Unsalted Roasted Peanuts (URP), Unsalted Roasted Hazelnuts (URH) and Salted Roasted Cashew nuts (SRC). These tests were conducted by a panel of 61 untrained tasters. 


\subsection{Statistical Analysis}

The results of the physicochemical characterization were presented with their means and their standard deviations. The comparison of the descriptors of the sensory profiles was performed by the test of Student $(\alpha=5 \%)$. The preference test in pair was implemented by comparing the value of $z$ (with $z=k-(1 / 3) n /(2 / 9) n$, where $\mathrm{k}$ is the strongest value between the number of volunteer who preferred each of the two appetizers and $\mathrm{n}$ is the total number of volunteers) to the probability $\mathrm{t} \alpha, \infty(\mathrm{T} \alpha, \infty=1.645$ with $\alpha=0.05)$ in the Student table (Meilgaard et al., 1999). The preference test by classification was performed by the test of Friedman $(\alpha=0.05)$, followed by the test of the least significant difference (LSD) (Meilgaard et al., 1999).

\section{Results}

\subsection{Physicochemical Characterization}

The fresh kernels of Terminalia catappa collected have a moisture content of $3.77 \pm 0.38 \%$. Their mean nutrients contents are $4.0 \pm 0.00 \%, 40.95 \pm .30 \%, 50.66 \pm 1 \%, 1.35 \% \pm 0.1 \%, 0.27 \pm 0.01 \%$ for ash, protein, fat, total sugars and reducing sugars respectively. The fat extracted from extracted has an acid value of $1.35 \%$ and a peroxide value of $6.27 \mathrm{meq} \mathrm{O}_{2} / \mathrm{kg}$.

Table 1. Mean values of physicochemical characteristics of fresh kernels of Terminalia catappa

\begin{tabular}{|c|c|c|}
\hline \multicolumn{2}{|c|}{ MEASURED PARAMETERS } & VALUES \\
\hline \multicolumn{2}{|c|}{ Extraction yield (\%) } & $19.73 \pm 1.10$ \\
\hline \multicolumn{2}{|c|}{ Moisture (\%) } & $3.77 \pm 0.38$ \\
\hline \multicolumn{2}{|c|}{ Ash (\%) } & $4.0 \pm 0.00$ \\
\hline \multicolumn{2}{|c|}{ Crude proteins $(\%)$} & $40.95 \pm 1.30$ \\
\hline \multirow{4}{*}{ Lipids } & Fat content $(\%)$ & $50.66 \pm 1.0$ \\
\hline & Acid value (\%) & $1.34 \pm 0.15$ \\
\hline & Peroxyde value (meq $\mathrm{O}_{2} / \mathrm{kg}$ ) & $6.27 \pm 0.20$ \\
\hline & Reducing sugars (\%) & $1.35 \pm 0.10$ \\
\hline Sugars & Total sugars (\%) & $0.27 \pm 0.01$ \\
\hline
\end{tabular}

\subsection{Sensory Evaluation}

\subsubsection{Sensory Profiles of Appetizers Concocted from the Kernels of Terminalia Catappa}

Table 2 presents the averages of the scores obtained for each descriptor of the sensory profile of Terminalia concoted kernels. These results show that the Unsalted Roasted Kernels (URK) and the Roasted Salted Kernels (RSK) are not significantly different $(\mathrm{p}>0.05)$ in terms of the attributes sweet and oily but differ significantly $(p \leq 0.05)$ for the attributes firm, salty and bitter. It should be noticed that the concocted appetizers present high intensities for the attributes firm (76 and $78.8 \mathrm{~mm}$ for URK and SRK respectively) and oily (85.8 and $84.8 \mathrm{~mm}$ for URK and SRK respectively). The score of salted kernels (SRK) for the descriptor bitter is significantly higher $(\mathrm{p} \leq 0.05)$ than that of unsalted kernels (URK).

Table 2. Comparison of sensory profiles of the appetizers concocted from the kernels of the fruits of Terminalia catappa

\begin{tabular}{llllll}
\hline \multirow{2}{*}{ ITEM } & SWEET & SALTY & BITTER & FIRM & OILY \\
& {$[\mathrm{mm}]$} & {$[\mathrm{mm}]$} & {$[\mathrm{mm}]$} & {$[\mathrm{mm}]$} & {$[\mathrm{mm}]$} \\
\hline Unsalted Roasted Kernels (URK) & $26.9 \mathrm{a}$ & $7.5 \mathrm{~b}$ & $6.0 \mathrm{~b}$ & $76.0 \mathrm{~b}$ & $85.8 \mathrm{a}$ \\
Salted Roasted Kernels (SRK) & $28.8 \mathrm{a}$ & $23.2 \mathrm{a}$ & $11.2 \mathrm{a}$ & $78.8 \mathrm{a}$ & $84.8 \mathrm{a}$ \\
\hline
\end{tabular}

The averages followed by the same letter, in a given column, are not significantly different ( $>0.05)$. 


\subsubsection{Paired Preference Test}

Tasters' preference between the two Terminalia-based appetizers (URK and SRK) is presented in Table 3. No significant difference $(\mathrm{p}>0.05)$ appeared between tasters' preference for both appetizers.

Table 3. Tasters' preference of the Terminalia-based kernels appetizers

\begin{tabular}{ll}
\hline \multicolumn{1}{c}{ ITEM } & Number of tasters who preferred the appertizer \\
\hline Unsalted Roasted Kernels (URK) & 33 a \\
Salted Roasted Kernels (SRK) & $28 \mathrm{a}$ \\
\hline
\end{tabular}

Numbers followed by the same letter in a column are not significantly different $(\mathrm{p}>0.05)$.

\subsubsection{Preference Ranking Test}

The results of the comparison of the two concoted Terminalia-based appetizers to other appetizers are presented in Table 4. The preference order is the following: $\mathrm{URH}<\mathrm{URK}<\mathrm{SRK}<\mathrm{URP}<\mathrm{SRC}<\mathrm{SRP}$.

Table 4. Comparison of Terminalia-based appetizers to other commonly consumed appetizers

\begin{tabular}{llllllll}
\hline & SRP & SRC & URP & SRK & URK & URH \\
\hline Sum of ranks & 72 & 117 & 184 & 258 & 296 & 357 \\
Preference order & $1 \mathrm{a}$ & $2 \mathrm{ba}$ & $3 \mathrm{~b}$ & $4 \mathrm{c}$ & $5 \mathrm{c}$ & $6 \mathrm{~cd}$
\end{tabular}

Ranks followed by the same letter are not significantly different ( $\mathrm{p}>0.05)$.

RSK: Roasted Salted Terminalia Kernels; URK: Unsalted Roasted Terminalia Kernels.

URP: Unsalted Roasted Peanuts; URH: Unsalted Roasted Hazelnuts.

RSP: Roasted Salted Peanuts; SRC: Salted Roasted Cashew nuts.

\section{Discussion}

The high protein levels $(40.95 \pm 1.30 \%)$ and lipids $(50.66 \pm 1 \%)$ of the kernels of Terminalia catappa account for their good nutritional value. The protein content is similar to that of soybeans $(40 \%)$ known for their high protein content (Obatolu, Osho, \& Oyekan, 1993). Moreover, this protein level is about two times higher than those reported by various authors (Matos et al., 2009; Oduro et al., 2009; Oliveira et al., 2000; Ezeokonkwo \& Dodson, 2004 ) that are between $22.1 \%$ and $29.4 \%$. The fat content $(50.66 \pm 1 \%)$ is similar to the values reported by Oleveira et al. (2000) and Matos et al. (2009), which are $58 \pm 029 \%$ and $51.80 \%$ respectively. However, this amount is higher than the level (36.9\%) obtained by Obatolu et al. (1993) for soybeans. Oleveira et al. (2000) have reported that this value is comparable to those of other oilseeds such as peanut, castor bean, rapeseed and sunflower which have lipid content varying from 43.7 to $54.7 \%$ (dry matter base). Their high lipid content bestows on fresh kernels a good source of energy, equivalent to $456 \pm 9 \mathrm{kcal}$. Nag and De (1995) stated that the oil of Terminalia catappa seeds is very promising for edible purposes. The acid and peroxide values $(1.34 \pm 0.15 \%$ and $6.70 \pm 0.20 \mathrm{meq} / \mathrm{kg}$ oil respectively) are lower than the values recommended for peanut oil by the codex Alimentarius ( $4 \%$ and 15 meq $\mathrm{O}_{2} / \mathrm{kg}$ oil respectively). This result shows that the kernels used to prepare the appetizers were of good hygienic quality (FAO/WHO, 1992). A comparison of sensory profiles of Salted Roasted Kernels (SRK) and Unsalted Roasted kernels (URK) from Terminalia catappa reveals that they differ in the attributes salty, bitter and firm. Although, both concocted kernels are much firm and oily. High firmness is a common property to seeds or nuts. The oiliness of the kernels is due to their high fat content $(50.66 \pm 1 \%)$, and 
may be strengthened by the roasted process. The kernels have the same taste in term of sweetness but the salty ones are most bitter. The adding of salt to kernels leads to a bitter taste. This can be explained by concentration of bitter compound such as alkaloids, saponins and some glycosides in kernels, consecutively to the release of water caused by the plasmolysis effect of the salt. Nevertheless, only alkaloids were found in Terminalia catappa nuts (Oduro et al., 2009). Despite differences in their attributes, tasters' preference for both appetizers shows that URK and SRK are equally preferred. In other words, the preference for both appetizers is not influenced by differences in their sensory profiles. Moreover, even if both appetizers are as much preferred as unsalted roasted hazelnuts, the tasters have expressed a marked preference for Roasted Peanuts (salted or not) and Roasted Salted Cashew nuts. Terminalia catappa kernels are reported to taste like commercially grown almonds (Agatemor \& Ukhun, 2006), this is proved by taster's same preference for Terminalia-based appetizers and hazelnuts.

\section{Conclusion}

The results of this study have confirmed the fact that Terminalia catappa has a good nutritional value with high contents in proteins and lipids. The appetizers concocted (Salted Roasted kernels and Unsalted Roasted Kernels), while equally preferred by tasters, displayed different sensory profiles with a significant difference for the descriptors firm, bitter, and salty. Besides, these two Terminalia -based appetizers were as much preferred as the Unsalted Roasted Hazelnuts (URH). However, they were less preferred than the Roasted Peanuts (salted or not) and the Roasted Salted Cashew nuts. In an attempt to popularize this tree and its by-products, further improvements in the concoction of appetizers from its kernels would prove useful.

\section{References}

Agatemor, C., \& Ukhun, M. E. (2006). Nutritional potential of the nut of tropical almond (Terminalia Catappa L.). Pakistan Journal of Nutrition, 5(4), 334-336.

Association of Official Analytical Chemists [AOAC]. (1975). Analytic Official Methods of Analysis of the Association of Chemists (12th ed.). Washington DC, 626-627.

Attaie, H., Zakhia, N., \& Bricas N. (1998). Etat des connaissances et de la recherche sur la transformation et les utilisations alimentaires de l'igname. In J.-L. Marchand, \& B. Girardot (Ed.), L'igname, plante séculaire et culture d'avenir (pp. 275-284). Montpellier, France : CIRAD-IRD.

Atnasooriya, W. D., \& Dharmasiri, M. G. (2000). Effect of Terminalia catappa on sexual behaviour and fertility of male rats. Asian Journal of Andrology, 2, 213-219.

Bernfeld, P. (1955). Amylase, $\alpha$ and $\beta$. In S. Colowick, \& N. O. Kaplan (Eds.), Method in enzymology (Vol. 1, pp. 149-158). New-York, NY: Academic Press. http://dx.doi.org/10.1016/0076-6879(55)01021-5

Bureau Interprofessionnel d'Etudes Analytiques [BIPEA] (1976). Recueil des méthodes d'analyses des communautés européennes. Gennevilliers, France.

Cavalcante, M. A., Maia, G. A., Figuieredo, R. W., \& Teeixeira, E. A. M. (1986). Caracteristicas fiscas e quimicas da castanhola, Terminalia catappa L. Ciência Agronômica, 17, 111-116.

Cocks, L. V., \& Rede, V. (1996). Laboratory Handbook for Oil and Fat Analysts. New York, NY: Academic Press.

Dikshit, M., \& Samudrasok, R. K. (2011). Nutritional evaluation of outer fleshy coat of Terminalia catappa fruit in two varieties. International Journal of Food Science and Nutrition, 62, 47-51.

Dorsch, W., \& Wagner, H. (1991). New antiasthmatic drugs from traditional medicine? International Archives of Allergy and Applied Immunology, 94, 262-265.

Dos Santos, I. C. F., De Carvalho, S. H. V., Solleti, J. I., Ferreira, S. W., Teixiera, D. S. S. K., \& Meneghetti S. M. P. (2008). Studies of Terminalia catappa L. oil: Characterization and biodiesel production. Bioresource Technology, 99, 6545-6549.

Dubois, M., Gilles, K., Hamilton, J. D., Rebers, A., \& Smith, M. (1956). Colorimetric methods for determination of sugars and related substances. Analytical Chemistry, 28, 350-356.

Ezeokonkwo, C. A., \& Dodson, W. L. (2004). The potential of Terminalia catappa (Tropical almond) seed as a source of dietary protein. Journal of Food Quality, 27(3), 207-219. http://dx.doi.org/ 10.1111/j.1745-4557.2004.tb00650.x.

FAO/WHO. (1992). Programme mixte FAO/OMS sur les normes alimentaires. Rome, Italy: FAO.

Ko, T. F., Weng, Y. M., \& Chiou, R. Y. (2002). Squalene content and antioxidant activity of Terminalia catappa 
leaves and seeds. Journal of Agricultural and Food Chemistry, 50(9), 5343-5348. http://dx.doi.org/10.1021/jf0203500

Ko, T. F., Weng, Y. M., Lin, S. B., \& Chiou, R. Y. (2003). Antimutagenicity of supercritical $\mathrm{CO}_{2}$ extracts of Terminalia catappa leaves and cytooxicity of extracts to human heptoma cells. Journal of Agricultural and Food Chemistry, 51(12), 3564-3567.

Lin, C. C., Hsu, Y. F., \& Lin, T. C. (1999). Effect of punicalagin and punicalin on carrageen-induced inflammation in rats. The American Journal of Chinese Medicine, 27(3-4), 371-376.

Matos, L., Nzikou, J. M., Kimbonguila, A., Ndangui, C. B., Pambou-Tobi, N. P. G., Abena, A. A., \& Desobry, S. (2009). Composition and nutritional properties of seeds and oil from Terminalia catappa L. Advance Journal of Food Science and Technology, 1(1), 72-77.

Meilgaard, M., Civille, G. V., \& Carr, B. T. (1999). Sensory evaluation techniques (3rd ed.), Boca Raton, Fl: CRC Press LLC.

Nag, A., \& De, K. B. (1995). In search of a new vegetable oil. Journal of Agricultural and Food Chemistry, 43(4), 902-903.

Nagappa, A .N., Thakurdesai, P. A., Venkat, R. N., \& Singh, J. (2003). Antidiabetic activity of Terminalia catappa Linn fruits. Journal of Ethnopharmacology, 88, 45-50.

Nwosu, F. O., Dosumu, O. O., \& Okocha, J. O. C. (2008). The potential of Terminalia catappa (Almond) and Hyphaene thebaica (Dum palm) fruits as raw materials for livestock feed. African Journal of Biotechnology, $7(24), 4576-4580$.

Obatolu, V. A., Osho, S. M., \& Oyekan, P. M. (1993). Fortification of indigenous foods using soybeans for the South Western States of Nigeria. Ibadan, Nigeria, IITA and IAR publication.

Oduro, I., Larbie, C., Amoako, T. N. E., \& Antwi-Boasiako, A. F. (2009). Proximate composition and basic phytochemical assessment of two common varieties of Terminalia catappa. Journal of Science and Technology, 29 (2), 1-7.

Oliveira, J. T. A., Vasconcelos, I. M., Bezerra, L. C. N. M., Silveira, S. B., Monteiro, A. C. O., \& Moreira, R. A. (2000). Composition and nutritional properties of seeds from Pachira aquatica Aubl, Sterculia striata St Hil et Naud and Terminalia catappa Linn. Food Chemistry, 70, 185-191.

Teotia, S., \& Singh, M. (1997). Hypoglycemic effect of Prunus amygdalus seeds in albino rabbits. Indian Journal of Experimental Biology, 35(3), 295-296. http://dx.doi.org/10.1016/S0308-8146(00)00076-5 